\title{
An Interview with Professor Squire J. Booker: on Science and Diversity
}

\author{
Axel O. Vera ${ }^{1,2, *}$, Franklin J. Avilés Vázquez ${ }^{3, \#}$, and Edward D. Badding ${ }^{1, \#}$ \\ Edited by Manraj S. Gill
}

Squire J. Booker is an Evan Pugh University Professor of Chemistry and of Biochemistry and Molecular Biology at Pennsylvania State University (Penn State). He obtained a Ph.D. in biochemistry from MIT under Prof. JoAnne Stubbe. Prof. Booker's research on radical-dependent enzymes has unraveled some mechanisms of antibiotic resistance and natural product biosynthesis, and he was elected to the National Academy of Sciences in 2018. He is also an advocate for promoting diversity in science. He created and co-directs the Penn State Department of Chemistry Summer Research Experience for Undergraduates (REU) program, which allows 10 undergraduate students from the United States to conduct chemical research on the topic of "catalysis and motion" every year at Penn State. The program mainly recruits women, students from underrepresented groups, and students from universities and colleges that lack strong research infrastructure. Prof. Booker is also on the steering committee of the Annual Biomedical Research Conference for Minority Students (ABRCMS), one of the largest professional conferences for underrepresented students with over $\mathbf{5 0 0 0}$ yearly attendees, and is the Chair of the ABRCMS Chemistry Division. Here, we learn about Prof. Booker's trajectory in science, how he became a faculty member, and his efforts to increase diversity in science. This interview was edited for clarity.

Science Policy Review: What motivated you to pursue a B.S. in chemistry and become a scientist?

Squire J. Booker: I went to Austin College, a small college in Sherman, Texas, thinking of studying pre-medicine like some of my friends, but at the same time, I really wanted to be a chemical engineer because of my uncle, a professor who promoted diversity initiatives within engineering in Beaumont, Texas. I liked the chemical aspect of engineering, but I never considered becoming a chemist because I did not know what chemists do. Since Austin College did not have a chemical engineering program, and I believed there were more job

\footnotetext{
${ }^{1}$ Department of Chemistry, Massachusetts Institute of Technology, Cambridge, $\mathrm{MA}$

${ }^{2}$ Chemical Biology and Therapeutics Science, Broad Institute of MIT and Harvard, Cambridge, MA

${ }^{3}$ Department of Biophysics and Biophysical Chemistry, Johns Hopkins University, Baltimore, MD

\# These authors contributed equally

*Email: axelvera@mit.edu
}

The authors declare no conflict of interest. The opinions presented here represent the opinion of the speaker, not MIT Science Policy Review.

(c) 2021 The Author(s)

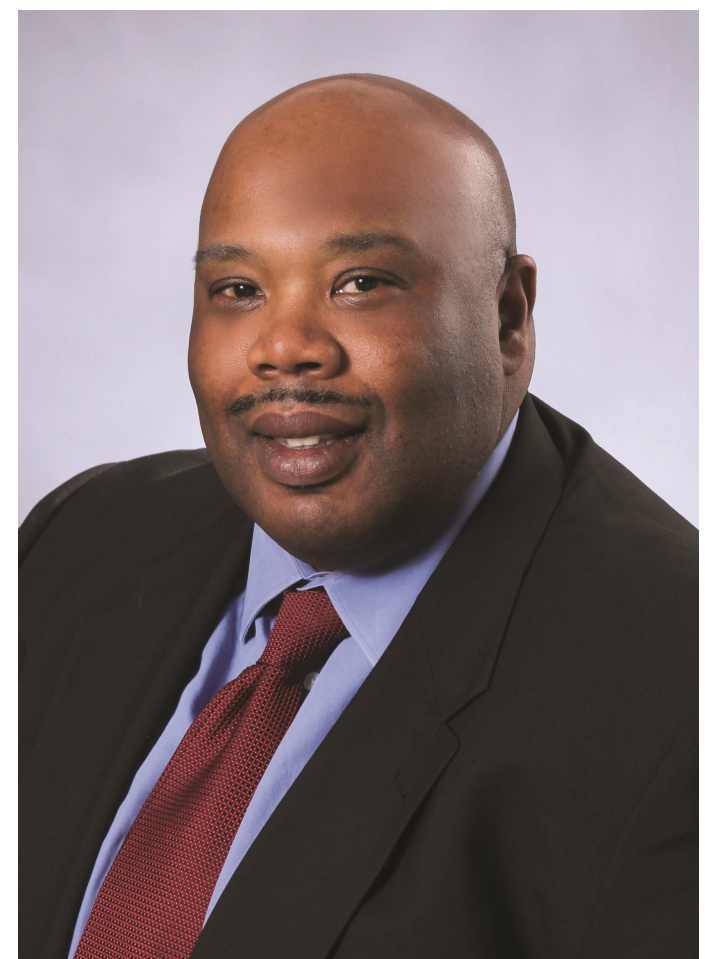

Figure 1: Professor Squire J. Booker.

opportunities as a chemist than as a biologist outside of medicine, I pursued a B.S. degree in chemistry. Back in 1983, there were little research opportunities, so what motivated me to become a scientist and a chemist was taking a physical organic chemistry class and the fact that Joseph Francisco, whom I knew from my neighborhood, became a chemist and earned a PhD from MIT.

SPR: How crucial was the MIT Summer Research Program (MSRP) for you to decide to pursue graduate school at MIT?

SJB: Joseph Francisco called me one day and said MIT, for the first time, was putting together this fully-funded summer research program for underrepresented minorities. I applied and worked for Bill Orme-Johnson and Christopher Walsh. I studied this poorly understood nickel-containing enzyme that took hydrogen gas and passed its electrons onto an external acceptor. At MSRP, I learned how to purify proteins and how to 
assess their purity and activity, which are fundamental things in biochemistry. The goal of MSRP was to get us to apply to MIT. From our cohort of eight students, three of us were subsequently admitted to MIT.

\section{SPR: Did your MSRP mentors encourage you to apply} to MIT for graduate school?

SJB: I do not remember any specific encouragement for me to apply to MIT, other than the one I received from Andrew Kolodziej, the student that directly supervised me. He encouraged me to apply to MIT and told Bill Orme-Johnson that he thought I was capable of succeeding at MIT.

SPR: We have all struggled in graduate school, particularly now during the COVID-19 pandemic. Did you face any particular challenges transitioning to graduate school or throughout your time at MIT? If so, how did you face the challenges and surpass them?

SJB: I faced many challenges. One of them was joining a lab in my first semester at MIT. I was scared to go talk to professors because I thought they were going to realize how little I knew and think they made a mistake by accepting me. My goal was to stay under the radar because my peers told me stories of MIT professors telling them, "You are not good enough to work for me." I would have been devastated if that happened to me.

JoAnne Stubbe arrived to MIT the year I joined. The reason I initially got interested in JoAnne's lab was because my friend Marty Bollinger, whom I considered the top person in our cohort, joined JoAnne's lab. So, I thought - I will do whatever Marty does. I then talked to JoAnne, and she asked me what type of research I had done. I was still insecure about my research experience and started to tense up, so she quickly added, "Actually, I do not want to hear it. The less research experience you have, the better because I will not have bad habits to break and will not have to retrain you." Once she said that, I knew I was in the right place.

SPR: Why was choosing to pursue postdoctoral research the right fit for you? Any particular memories of your time in France or Wisconsin?

SJB: At the time, it was common to do a postdoc because there were not many jobs in biochemistry. However, there was one university, because of the diversity thing, that tried to hire me as faculty before doing a postdoc. I discussed this with JoAnne and she told me that I would get other offers because she thought I was very good. I was shocked by this because JoAnne did not give a lot of compliments.

Since I always wanted to go to France, I decided to join Daniel Mansuy's lab at Université René Descartes in Paris. They did not have anyone who could purify proteins, and I was good at it. In graduate school, the purification of the protein I was studying took about seven days and I basically could not go home until the protein was purified and frozen. I brought this same type of rigor and determination to my lab in France. People thought I was crazy to work through the night to purify this protein, but they loved me because now they had protein

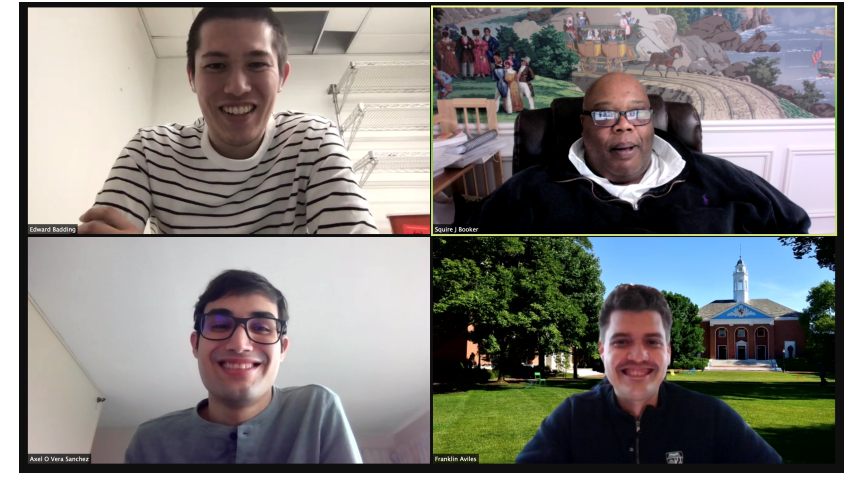

Figure 2: Professor Squire J. Booker with interview team members Edward Badding, Axel Vera, and Franklin Avilés Vázquez (counter-clockwise from the top right corner).

to test their molecules for inhibition. I had a wonderful time in France. The lab was close to the Louvre, Musée d'Orsay, Les Deux Magots, and it was beautiful. Then I moved to Wisconsin for a second postdoc experience in Perry Frey's lab. What I really liked was that all the faculty at Wisconsin were very personable and were super excited about science. They also had an amazing library, and I loved to just go there, sit, and read.

SPR: What motivated you to become a faculty member and how did you become a faculty member at Penn State?

SJB: When I first met with Perry Frey, he asked me what I wanted to do, and I said academia, so he tailor made my experience at Wisconsin based on that. He was an associate editor of the journal Biochemistry (I am an associate editor now), so he would send me papers to review. I also taught some of his classes, and this helped me get ready for a faculty position. I think faculty mentoring is crucial. We need to teach young faculty how to develop strong proposals, and this is why I now run a grant writing workshop for aspiring faculty.

I never sought my faculty position. What happened was that while I was a postdoc, JoAnne and Perry gave talks at Penn State about my work. Penn State became interested in me, and Marty Bollinger, who knew me from JoAnne's lab and is now my colleague at Penn State, facilitated the introduction. I interviewed in the Department of Biochemistry and Molecular Biology and they subsequently offered me the job. So, they came looking for me rather than me for them. Universities now are even more proactive in recruiting people from minority backgrounds because they know they have to do much better with diversity, and there is a lot of competition for getting the best people.

\section{SPR: What is it like to lead a lab?}

SJB: In one respect, it is amazing. I can work on what I want to work on, and I work with people that support me and I support them in terms of mentoring. At the same time, however, it is nerve-racking. I am always concerned about giving someone a project that is not going to work out because they have to graduate within a certain timeframe. We also have to get stuff done if we want to maintain funding for the 
lab. Funding organizations want results, and having to chase money can also be nerve-racking. I would hate to tell my trainees that I do not have the money to support them. So, I feel blessed that I have always had sufficient money to keep them employed.

SPR: Any advice to young faculty or aspiring graduate students/postdocs?

SJB: You want to make sure that you are passionate about what you are doing. Also, the ability to write and communicate is really important in science. Even if you do not know what you are doing, if you are able to secure enough grant money, you can hire someone who does.

SPR: The ability to write and communicate is such a great point. I just went through the process of applying to fellowships and one reviewer gave me an excellent evaluation but the other one did not like my proposal at all. So, I learned that I need to have the ability to write my proposal in a way that it appeals to both the expert and non-expert reviewer.

SJB: You are probably talking about something related to the National Science Foundation (NSF). I had an NSF grant and I got four excellent reviews, and then the fifth person gave me a poor review, so my grant was judged as "low priority". Luckily, the NSF director realized there was something wrong and the NSF gave me the grant anyway. We published a Science paper on this. You never know where some of these comments come from, so I tell people not to take all of this personally. Still, I see people on Twitter being devastated because they did not get an NSF Graduate Research Fellowship. Most people do not get an NSF Graduate Research Fellowship and it does not mean anything about their future success, so people should not be so distraught about this.

SPR: What has it been like forming and managing the REU program at Penn State?

SJB: The REU has been a joy. I am the Primary Investigator of the program, but I have Tiffany Mathews and Lara Sittler who run the day-to-day affairs. It is pretty fun and we have gotten some incredible people. Last year we had, eight students in the REU and five of them came back to Penn State for graduate school, which I think is pretty impressive.

SPR: Any advice to student groups and institutions trying to form chemistry summer undergraduate research programs? What would you recommend to get other research universities to invest in these programs?

SJB: Many institutions can call alumni and ask them to fund these programs. Another option is for faculty to write grants to fund these programs as I do in Penn State. I am happy to share my grant towards this effort with you. For our REU, I submit a grant every three years. Penn State faculty are very collegial, so I do not mind doing it because whenever I need something they quickly give it to me and they are very appreciative. So, it has not been difficult to do and the grants are not hard to write.
There are numerous REU programs at Penn State and we also collaborate with some of them. A lot of the stuff on these grants is boilerplate material such as: How many students do you plan to take? How much money is required for stipend and traveling? What type of research will the students be conducting? How are you going to assess the success of the program? It is also important for departments to encourage students in the program to apply and accept them for graduate school to keep the program going.

SPR: How did you become involved in ABRCMS and what is your current role in the ABRCMS Chemistry division?

SJB: I got involved in ABRCMS, because Avery August, the chair of the ABRCMS steering committee, contacted me. I have known Avery for a long time, because he and I started our careers at Penn State at the same time. I help decide what content is included in each meeting, I help select judges for chemistry posters, and I make sure all posters are judged.

SPR: When we attended ABRCMS we felt like there were less chemistry programs recruiting students in ABRCMS relative to biology programs? How do we get more chemistry departments involved in ABRCMS?

SJB: ABRCMS is happy to have any department that wants to go there and recruit. I think it is just because ABRCMS started off as a biomedical research conference. Still, we can probably do a better job at attracting chemistry departments in the future. I will talk to Avery about this. Many chemistry departments, such as Penn State's and Caltech's, currently attend ABRCMS. So, I think it is a matter of finding faculty in chemistry departments that are willing to attend and can create enough push within their department.

"I think the challenge, now, will be to help professors become better

mentors... I have taken classes to learn how to be a culturally sensitive mentor, and I also discuss strategies with other mentors... I am a big advocate of mentoring because I think people going into science need a coach to help them train and work things out, much like athletes have coaches."

SPR: Why is mentoring students from all levels of experience so important to you?

SJB: Just because it is fun. I am not concerned about undergraduate projects quickly leading to tangible results. It is not like they have to publish to get into graduate school, so you can get them to do things that are riskier. Most of the new projects in my lab, have been started by undergraduates and then passed to graduate students. Also, the two high school 
students that I have had, Martin McLaughlin and Edward Badding, both of whom matriculated at MIT, just turned out to be all stars, so mentoring them was easy.

SPR: How do you envision the training process of an academic scientist can be updated going forward to incentivize chemistry professors to mentor students from all levels of experience and to focus on outreach?

SJB: I think in general we are moving towards that direction. We are doing all this talk of diversity, nowadays, and there are already ways in which chemistry professors are incentivized to focus on mentoring and outreach. For example, you cannot get an NSF grant without demonstrating a significant level of mentoring and outreach.

I think the challenge, now, will be to help professors become better mentors. This is why I am a mentor in the $\mathrm{NIH}$ Maximizing Opportunities for Scientific and Academic Independent Careers (MOSAIC) program. For MOSAIC, minoritized postdocs write a grant which carries over to when they start their faculty position, and I mentor one of its recipients. I have taken classes to learn how to be a culturally sensitive mentor, and I also discuss strategies with other mentors. I think this stuff is going to catch on, and we are going to get better at it. I am a big advocate of mentoring because I think people going into science need a coach to help them train and work things out, much like athletes have coaches.

"Do not isolate yourself. Make sure

that you interact with people. There is

so much of science that you can

learn from other people. Many times,

underrepresented minorities will tend

to isolate themselves because many

of us have experienced unkind words

and this feeling that we do not

belong. So, we protect ourselves by

isolating ourselves and that is not

good."

SPR: What lessons have you learned about managing your time and effort between academic tasks and constructive public service and outreach?

SJB: I am often overwhelmed. The pandemic has at least given me a chance to think about things more deeply, and I have decided that I am going to do a lot less traveling in the future. There is only a certain amount of time in a day, and anytime that I spend doing other things is time that is taken away from people that I am supposed to be training. I think in the future, there is going to be a lot less of me out in public, so I can focus even more on science and mentoring.

SPR: What advice would you give underrepresented minority students pursuing careers in science?
SJB: Persistence, if it is something that you want to do, just keep at it. Do everything that you can to make yourself better at whatever you do. I remember being in certain classes or hearing certain talks and not understanding anything, and I would just keep it in the back of my head, and go to the library, or do whatever I had to do to figure it out.

Do not isolate yourself. Make sure that you interact with people. There is so much of science that you can learn from other people. Many times, underrepresented minorities will tend to isolate themselves because many of us have experienced unkind words and this feeling that we do not belong. So, we protect ourselves by isolating ourselves and that is not good. For example, MIT offered me a minority fellowship as a first-year graduate student because they wanted me to focus on my studies and not be distracted with teaching responsibilities. I declined because I wanted to balance taking classes with teaching like everyone else was doing. This is so important because when you start graduate school it is those relationships that you build with peers that help you succeed. If I would not have been a teaching assistant, I would have missed out on information. Peers can tell you how to approach a class or share practice exams with you. So, not isolating myself was probably the best thing I ever did.

You need to have confidence in yourself. Minoritized people tend to be a lot less confident than white males, for example. Because of their confidence, white males can get jobs at prestigious institutions, and it is these institutions that actually make them what they thought they were. If you put minoritized people in some of these institutions, they probably will do just as well. Therefore, you have to present yourself with confidence and rise to those types of challenges.

\section{Open Access}

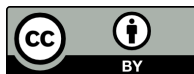

This MIT Science Policy Review article is licensed under a Creative Commons Attribution 4.0 International License, which permits use, sharing, adaptation, distribution and reproduction in any medium or format, as long as you give appropriate credit to the original author(s) and the source, provide a link to the Creative Commons license, and indicate if changes were made. The images or other third party material in this article are included in the article's Creative Commons license, unless indicated otherwise in a credit line to the material. If material is not included in the article's Creative Commons license and your intended use is not permitted by statutory regulation or exceeds the permitted use, you will need to obtain permission directly from the copyright holder. To view a copy of this license, visit http://creativecommons.org/licenses/ by $/ 4.0 \%$. 